\title{
Perineal Gland
}

National Cancer Institute

\section{Source}

National Cancer Institute. Perineal Gland. NCI Thesaurus. Code C77621.

A gland near the anus producing an odorous secretion. 